\title{
DETERMINATION OF OPTIMAL ALGAE CONCENTRATION FOR CONTINUOUS GROWTH OF Scenedesmus sp. IN CHU AND MODIFIED CHU MEDIA
}

\author{
K. R. Santos, ABSTRACT \\ and A. B. Mariano \\ Universidade Federal do Paraná \\ Departamento de Engenharia Mecânica \\ Bairro Jardim das Américas \\ CP. 19011, Curitiba, Paraná, Brasil \\ ribeiro.kassi@gmail.com \\ andrebmariano@gmail.com \\ Received: October 29, 2014 \\ Revised: November 30, 2014 \\ Accepted: December 30, 2014 \\ The high cost of production in the cultivation of microalgae in \\ photobioreactors is a barrier to be overcome, therefore is necessary to \\ search to reduce the cost of cultivation. The objectives of this work \\ are to compare the growth of the microalgae Scenedesmus sp. being \\ cultivated in CHU medium and in an alternative medium composed \\ mainly of fertilizer and to establish guidelines for growth under \\ continuous mode. The research approach consisted on growing the \\ microalgae in Erlenmeyer type photobioreactors and producing the \\ growth curves for both media. The comparisons between the two, \\ were made based upon three parameters: dry biomass, absorbance, \\ and total lipid quantity. The experiments were made in triplicates in \\ order to quantify the uncertainty in the measurements. The \\ comparison of the cultivation in both media suggest that the \\ modification of the chemical nutrients by fertilizer did not produce \\ significant changes in the number of cells, dry biomass and lipids. In \\ spite of that, the modification resulted in $20 \%$ cost reduction in the \\ growth medium. In this way, the substitution of conventional \\ nutrients by fertilizers, constitute an interesting alternative for the \\ production of biomass from microalgae leading to a cost reduction. \\ The results are used to develop strategies for continuous growth. \\ Keywords: microalgae, biofuel, fertilizer, culture medium, CHU, \\ continuous growth
}

\section{INTRODUCTION}

Due to human activities, air pollution in urban centers has become one of the major problems of society. Originating mainly from fossil fuels, which are used for power generation, transportation, and in industries such as the manufacture of cement, where there is a large generation of emissions of carbon dioxide $\left(\mathrm{CO}_{2}\right), \quad$ (Loera-Quezada, 2010). $\mathrm{CO}_{2}$ emissions from fossil fuels and cement have increased from $14.84 \mathrm{GtCO}_{2}$ (Gigatons of $\mathrm{CO}_{2}$ ) to $35.43 \mathrm{GtCO}_{2}$ in 2012. (CL Quéré, 2013) The replacement of diesel oil for biodiesel allows for cleaner transportation systems, resulting in improved air quality (Sales et al., 2006). Biodiesel can be produced from various raw materials such as vegetable oils, used cooking oils and animal fat, (Prabakaran \& Ravidran, 2011). The biodiesel produced by plants require a large planting area, for example, in the United States would require 330 million to 450 million hectares to meet $50 \%$ of the energy demands of transportation (Chisti, 2007). Competition with food and availability of planting area limits its production. Therefore, other sources of raw material such as microalgae are being investigated.
Microalgae are single-celled organisms with a fast growth rate that performing photosynthesis and have a high oil content and rapid biomass production (Minowa et al., 1995). The cultivation of microalgae is relatively simple compared to oilseed crops, they can be grown in smaller spaces and are used as a food supplement for humans and animals (Andrade \& Costa, 2008), in cosmetics and pharmaceutical applications.

The cultivation of microalgae in photobioreactors is promising from the point of view space due to the possibility of growing vertical structures and the possibility to better manage algae contamination. However, the high cost in the cultivation in photobioreactors is a barrier to overcome. The objectives of this work are to compare the growth of the microalgae Scenedesmus sp. being cultivated in CHU medium and in an alternative medium of lower cost composed mainly of fertilizer and to establish guidelines for growth under continuous operation mode that are expected to results in increase productivity.

In this work, experiments were performed with the microalgae Scenedesmus sp., which is part of the Phylum Chlorophyta. It is one of the most common green algae genres, found mostly in freshwater. 
Green algae are responsible for most of the production of molecular oxygen on the planet available from photosynthesis. They accumulate starch within their cells, and contain the pigments chlorophyll $\mathrm{a}$ and $\mathrm{b}$, carotenes and xanthophylls, the presence of chlorophyll $a$ end $b$ supports the idea that green algae were the ancestors of plants (Vidotti \& Rolemberg, 2004).

Besides water, a major portion of the operating cost in the cultivation of microalgae in photobioreactors are the added substrates critical to the growth. Table 1 contains the composition of Chu medium (Chu, 1942) a widely used medium for algae culture. Among the nutrients in the Chu medium, sodium nitrate has the largest concentration. We have developed a culture medium called modified-Chu with the substitution of urea by sodium nitrate and sodium phosphate (monobasic and dibasic) by superphosphate.

Table 1. Composition of the medium Chu and Modified - Chu.

\begin{tabular}{|c|c|c|c|c|}
\hline & \multicolumn{2}{|c|}{$\overline{\mathrm{CHU}}$} & \multicolumn{2}{|c|}{ Modified-CHU } \\
\hline Reagents & $\begin{array}{c}\text { Concentration } \\
\text { final medium } \\
\left(\mathrm{gL}^{-1}\right)\end{array}$ & $\mathrm{R} \$ \mathrm{~L}^{-1}$ & $\begin{array}{l}\text { concentration } \\
\text { the final } \\
\text { medium }\left(\mathrm{gL}^{-1}\right)\end{array}$ & $\mathrm{R} \$ \mathrm{~L}^{-1}$ \\
\hline Urea $-\left(\mathrm{NH}_{2}\right)_{2} \mathrm{CO}_{4}$ & - & - & 0.087 & 0.00088 \\
\hline Sodium nitrate $-\mathrm{NaNO}_{3}$ & 0.25 & 0.0059 & - & - \\
\hline $\begin{array}{c}\text { Calcium chloride } \\
\text { dihydrate }-\mathrm{CaCl}_{2} \cdot 2 \mathrm{H}_{2} \mathrm{O}\end{array}$ & 0.025 & 0.00063 & 0.025 & 0.00063 \\
\hline $\begin{array}{l}\text { Magnesium sulfate } \\
\text { heptahydrate - } \mathrm{MgSO}_{4} \cdot 7 \mathrm{H}_{2} \mathrm{O}\end{array}$ & 0.075 & 0.0111 & 0.075 & 0.0111 \\
\hline $\begin{array}{l}\text { Superphosphate } \\
\mathrm{Ca}\left(\mathrm{H}_{2} \mathrm{PO}_{4}\right)_{2} \mathrm{H}_{2} \mathrm{O}\end{array}$ & - & - & 0.175 & 0.00012 \\
\hline Dibasic potassium phosphate $-\mathrm{K}_{2} \mathrm{HPO}_{4}$ & 0.075 & 0.00414 & - & - \\
\hline $\begin{array}{l}\text { Monobasic potassium phosphate - } \\
\qquad \mathrm{KH}_{2} \mathrm{PO}_{4}\end{array}$ & 0.175 & 0.0079 & - & - \\
\hline Sodium chloride $-\mathrm{NaCl}$ & 0.025 & 0.00024 & 0.025 & 0.00024 \\
\hline EDTA - $\mathrm{C}_{10} \mathrm{H}_{14} \mathrm{~N}_{2} \mathrm{Na}_{2} \mathrm{O}_{8} \cdot 2 \mathrm{H}_{2} \mathrm{O}$ & 0.05 & 0.0024 & 0.05 & 0.0024 \\
\hline Potassium hydroxide - $\mathrm{KOH}$ & 0.031 & 0.0012 & 0.031 & 0.031 \\
\hline $\begin{array}{c}\text { ferrous sulfate } \\
\text { heptahydrate }-\mathrm{FeSO}_{4} \cdot 7 \mathrm{H}_{2} \mathrm{O}\end{array}$ & $4.8910^{-3}$ & 0.11 & $4.8910^{-3}$ & 0.11 \\
\hline Boric acid $-\mathrm{H}_{3} \mathrm{BO}_{4}$ & $11.4210^{-3}$ & 0.20 & $11.4210^{-3}$ & 0.20 \\
\hline $\begin{array}{l}\text { Zinc sulfate } \\
\text { heptahydrate - } \mathrm{ZnSO}_{4} \cdot 7 \mathrm{H}_{2} \mathrm{O}\end{array}$ & $8.8210^{-6}$ & 0.38 & $8.8210^{-6}$ & 0.38 \\
\hline $\begin{array}{l}\text { Manganese chloride } \\
\text { tetrahydrate }-\mathrm{MnCl}_{2} \cdot 4 \mathrm{H}_{2} \mathrm{O}\end{array}$ & $1.4410^{-6}$ & 0.67 & $1.4410^{-6}$ & 0.67 \\
\hline Molybdenum oxide $-\mathrm{Na}_{2} \mathrm{MoO}_{4} \cdot 2 \mathrm{H}_{2} \mathrm{O}$ & $1.1910^{-6}$ & 2.45 & $1.1910^{-6}$ & 2.45 \\
\hline $\begin{array}{c}\text { Copper Sulfate } \\
\text { pentahydrate }-\mathrm{CuSO}_{4} \cdot 5 \mathrm{H}_{2} \mathrm{O}\end{array}$ & $1.5710^{-6}$ & 0.04 & $1.5710^{-6}$ & 0.04 \\
\hline $\begin{array}{c}\text { Cobalt nitrate } \\
\text { hexahydrate }-\mathrm{Co}\left(\mathrm{NO}_{3}\right)_{2} \cdot 6 \mathrm{H}_{2} \mathrm{O}\end{array}$ & $0.4910^{-6}$ & 0.76 & $0.4910^{-6}$ & 0.76 \\
\hline Total & & 4.64 & & 3.74 \\
\hline
\end{tabular}

* Prices provided by DIELAB-Commerce Products Laboratories LTD. In the month of September 2012. 
As already mentioned, in order to make possible technical and economical cultivation of microalgae in photobioreactors for the production of biomass, there is a need to reduce costs of nutrients. Therefore, the aim of this study was to monitor the growth of the microalga Scenedesmus sp. in photobioreactors type flask, and the evaluation of the composition of the medium parameters: dry matter, absorbance and total lipids while grown in $\mathrm{Chu}$ and modified-Chu medium.

\section{MATERIALS AND METHODS}

For the preparation of modified-Chu, urea was used as nitrogen source and superphosphate as source of phosphorous (Mello et al., 2010). Urea is used as a synthetic fertilizer for plants for being $100 \%$ organic and containing $46 \%$ nitrogen (Urquiaga \& Malavolta, 2002). The superphosphate simple has ingredients derived from phosphorus, which can reduce nitrogen losses from the liquid to the gaseous state (Oliveira, Trivelin \& Oliveira, 2003).

A mass balance in all replaced reagents was made, in order to compute the contents of major components, nitrogen and phosphorus, which were then added to the modified-Chu.

Changes in the composition of the culture medium were motivated by the lower cost of alternative components to the usual reagents. These costs are listed in Table 1.

The experiment was conducted in a room with controlled temperature in the range 18 to $22{ }^{\circ} \mathrm{C}$, with illumination controlled to obtain a photoperiod of 12 hours a day (and 12 hours night) to match the normal day and night conditions. White fluorescent lamps were used, with an intensity of 2500 lux and aeration provided by continuous bubbling of air at 5 L. $\mathrm{min}^{-1}$.

The experiments were performed in triplicate, consisting of three Erlenmeyer flasks with Chu medium and three Erlenmeyer flasks with modifiedChu medium, each with a final volume of $1.6 \mathrm{~L}$. The Erlenmeyer flasks and all materials used in the preparation of the culture medium (pipettes, deionized water, nozzles, culture media) have previously been autoclaved at $125^{\circ} \mathrm{C}$ for 15 minutes, then cooled to room temperature to prevent possible contamination.

Before preparation of the experiment samples were collected from the inoculum to measure absorbance. This was used to standardize the beginning of the two experiments, which were started with 0.3 absorbance.

\section{ANALYSIS}

\section{Cells count}

The cell count was performed daily by light microscopy at 400x magnification. An aliquot of 1 $\mathrm{mL}$ was collected after manual shaking of the

Erlenmeyer in order to homogenize the cells that have decanted. The cell count was made using a Neubauer chamber with a mirror surface and a digital counter. Counting was carried out in the middle quadrant of the chamber, which contains 25 small squares. This quadrant was chosen for having more divisions, making it easier to count and therefore reducing the counting errors in cases with high cell concentrations.

Figure 1 shows the quadrant used and the counting direction. Results are expressed as number of cells $\mathrm{mL}^{-1}$.

B

\section{A}
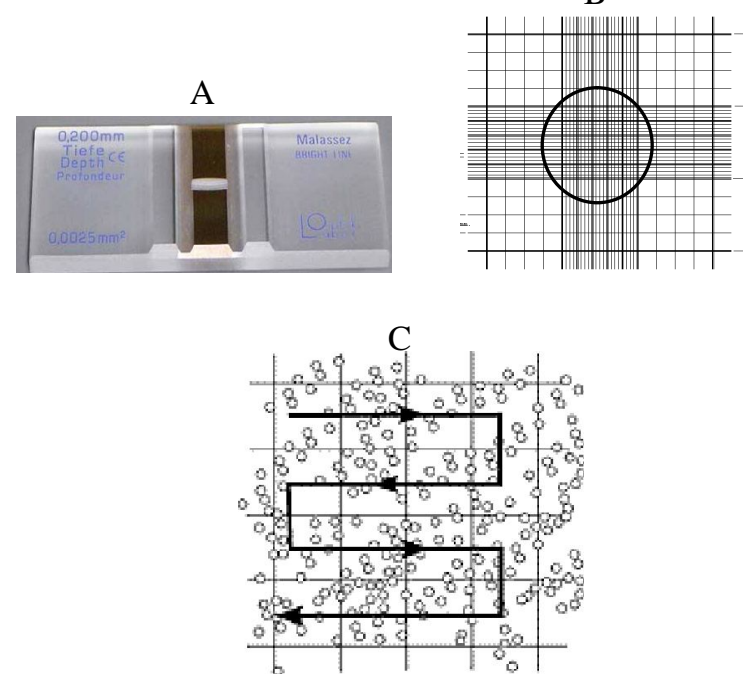

Figure 1. Schematic of the cell count in a Neubauer chamber. A) Neubauer chamber. B) Representation of a Neubauer chamber viewed under a microscope with $5 \mathrm{x}$ magnification. C) Counting direction in a Neubauer chamber. Source: A) Author. B) and C) Villarreal, 2009.

\section{Growth kinetics}

For the construction of the growth curve, the logistic equation (1) was used to find the profile that best described the experimental growth of the microalgae (Soares, 2010). The equation was fitted to the experimental data (cell density) by nonlinear regression.

$$
\mathrm{N}=\frac{\mathrm{N}_{\max }}{1+\left(\frac{\mathrm{N}_{\text {max }}}{\mathrm{N}_{0}}-1\right) \mathrm{e}^{-\mu \mathrm{t}}}
$$

where:

$$
\begin{aligned}
& \left.\mathrm{N}=\text { cell density (cells } \mathrm{mL}^{-1}\right) ; \\
& \mathrm{N}_{0}=\text { initial cell density }\left(\text { cells } \mathrm{mL}^{-1}\right) ; \\
& \mathrm{N}_{\max }=\text { maximum cell density }\left(\text { cells } \mathrm{mL}^{-1}\right) ; \\
& \mu=\text { specific growth rate }\left(\text { cell } \mathrm{dia}^{-1}\right) ; \\
& \mathrm{t}=\text { cultivation time (days). }
\end{aligned}
$$




\section{Absorbance}

The absorbance measurement was performed as an indirect measure of microalgae growth in both culture media. We used a wavelength of $540 \mathrm{~nm}$ for the incident radiation, using polymethylmethacrylate semi-micro cuvettes with $1.5 \mathrm{ml}$. The blank used was distilled water maintained at room temperature. The measurements were performed on a Lambda 25 spectrophotometer connected to a computer.

The measurement was performed daily from a sample collected from the $1.5 \mathrm{ml}$ Erlenmeyer flasks always taking care homogenizing the material before the measurement.

\section{Dry biomass}

The dry weight was determined through a gravimetric method and the results expressed in $\mathrm{gL}^{-1}$. From these measurements it was possible to determine the productivity of the culture.

The determination of dry biomass was made every two days by vacuum filtration using a glass fiber filter paper with pore diameter of $47 \mathrm{~mm}$. The filter paper was kept in an oven at $60{ }^{\circ} \mathrm{C}$ for 24 hours and then kept for 15 minutes in a desiccator with silica under vacuum, to remove additional moisture, and then weighted using an analytical balance. Filtration was carried out starting from a $25 \mathrm{~mL}$ sample collected from each flask (Chu and modified -Chu triplicates). With the help of a vacuum pump Te-O581, the sample was filtered on the pre-weighted paper. The papers with biomass were kept in the same conditions described for the filter paper $(24 \mathrm{~h}$ in oven at $60^{\circ} \mathrm{C}$ and $15 \mathrm{~min}$ in desiccator) and weighted. The mass of the dried biomass is calculated as the difference between the mass of paper with biomass and paper without biomass.

\section{Determination of lipids}

For determination of lipids $500 \mathrm{~mL}$ were collected. Using the method of Bligh and Dyer (1959) adapted for the extraction of lipids from microalgae it was possible to assess the total amount of neutral lipids present in the sample. This analysis was performed at the end of culture (day $13^{\circ}$ ).

The collected sample was flocculated using $\mathrm{NaOH}$. To each $100 \mathrm{~mL}$ sample $0.5 \mathrm{~mL} \mathrm{NaOH}$ were added (Morais, 2011) and stirred for 3 minutes at high speed and 10 minutes at low speed. After waiting around 20 minutes for the settling of the flocs of microalgae, the supernatant was discarded and the flakes were filtered using quantitative filter paper and a vacuum pump. The biomass paper was scraped carefully and then transferred to a petri dish. The dish was placed for $24 \mathrm{~h}$ to dry in an oven at $60^{\circ} \mathrm{C}$. The dry biomass was manually crushed into a powder microalgae.

A $0.05 \mathrm{~g}$ sample of microalgae was weighted and transferred to a polypropylene tube of $12 \mathrm{~mL}$ which was called tube 1 .

$3 \mathrm{~mL}$ of chloroform: methanol (2:1, v: v) were added and $10 \mu \mathrm{L}$ of a solution of butyl hydroxy toluene - BHT (1\% in methanol) into tube 1 and the compound subjected to ultrasound in an sonicator for 3 cycles of 15 minutes each. Then the tubes were incubated for 24 hours at $4{ }^{\circ} \mathrm{C}$ protected from light with aluminum foil wrapped to avoid photooxidation.

Further, the tubes were sonicated again for three cycles every 15 minutes and centrifuged at 5,000 rpm for 5 minutes at $5{ }^{\circ} \mathrm{C}$. The supernatant was recovered with a Pasteur pipette and stored in another tube (tube 2).

$1.5 \mathrm{~mL}$ of chloroform: methanol $(2: 1, \mathrm{v}: \mathrm{v})$ were added, in the sedimented biomass tube (1) which was centrifuged again at 5,000 rpm for 5 minutes at $5^{\circ} \mathrm{C}$. The supernatant was recovered and again transferred to tube 2 .

$2 \mathrm{~mL}$ of distilled water were added and $1 \mathrm{ml}$ chloroform to tube 2 . Then, the tube was shaken on a vortex and centrifuged at 5,000 rpm for 10 minutes at $5{ }^{\circ} \mathrm{C}$. The lower phase was recovered with a Pasteur pipette and stored in a glass vial called V1, previously weighed on analytical balance.

To the aqueous phase (second tube) $1 \mathrm{~mL}$ of chloroform was added. The tube was then shaken and centrifuged at 5,000 rpm for $10 \mathrm{~min} .5^{\circ} \mathrm{C}$, recovering the lower phase and transferring to a glass vial. The vial was left in a laminar flow hood to evaporate the solvent. Then the vial was again quantified its mass.

To determine the total lipid content, we used the gravimetric method. The results were presented as percentage of total lipids per gram of dry biomass.

The fraction of total lipids in \% was determined as follows:

$$
\text { Lipids }(\%)=\frac{\left(\mathrm{L}_{2}-\mathrm{L}_{1}\right) \times 100}{\mathrm{C}}
$$

where:

$$
\begin{aligned}
& \mathrm{L}_{1}-\text { mass of the empty vial }(\mathrm{g}) ; \\
& \mathrm{L}_{2}-\text { mass of the vial with lipids }(\mathrm{g}) ; \\
& \mathrm{C}-\text { dry biomass }(\mathrm{g})
\end{aligned}
$$

\section{RESULTS AND DISCUSSION}

Nitrogen has great importance for the development of microalgae being part of its primary metabolism. Phosphorus is also important because of its role in energy exchange and the formation of structural molecules (Lourenço, 2006).

In this study sodium nitrate was exchanged by urea with $46 \%$ nitrogen content (Urquiaga \& Malavolta, 2002), and a much lower cost. The microalga Scenedesmus sp. was grown for 13 days. During this period dry matter and total lipids were analyzed to define productivity. Secondary analyzes were also conducted to assess the growth of 
microalgae to assess the quality of the modified culture medium.

Figure 2 illustrates the cell growth during 13 days obtained from direct cell count for both the Chu and modified-Chu media. The cell density as a function of time allows evaluating the speed and the minimum and maximum cell density of the two culture media. In Figure 2 the markers represent the average of the three samples; the solid lines correspond to a logistic fit using the logistic equation (Eq. (1)). The error bars were obtained using \pm 2 times the standard deviation of the measurements. Thus the range of values covered by the error bars represent statistically $\pm 95 \%$ of the population (Cumming et al., 2007).

Figure 3 illustrates the relationship between the cellular concentration and absorbance at $540 \mathrm{~nm}$. It is observed from Figure 3 that the cell density did not change much in the two culture media until the $8^{\text {th }}$ day. After that day there was a small decline in the cell density of the modified-Chu medium.

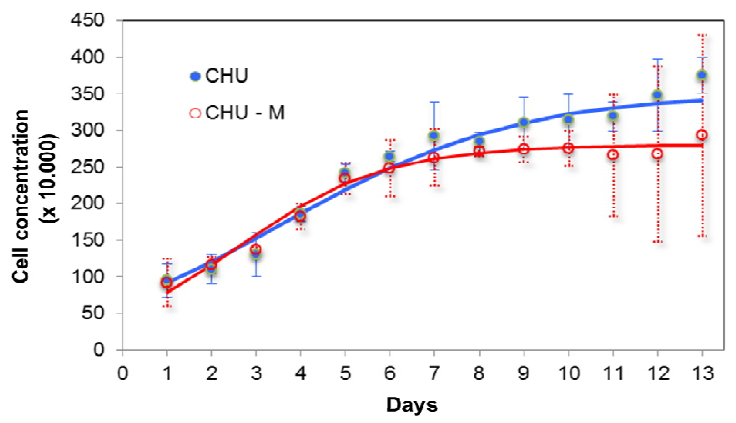

Figure 2. Growth curve of cell culture with Chu and modified-Chu media. Average cell count; logistic adjustment and standard deviation.

Figure 3 illustrates a linear relationship between cell concentration and absorbance. The result of Figure 3 can be used in the laboratory for a rapid estimation of the number of cells in a culture from reading the absorbance, a method widely used in microbiology. Nevertheless, for higher reliability of the results, this estimate was not considered for evaluation of cell density.

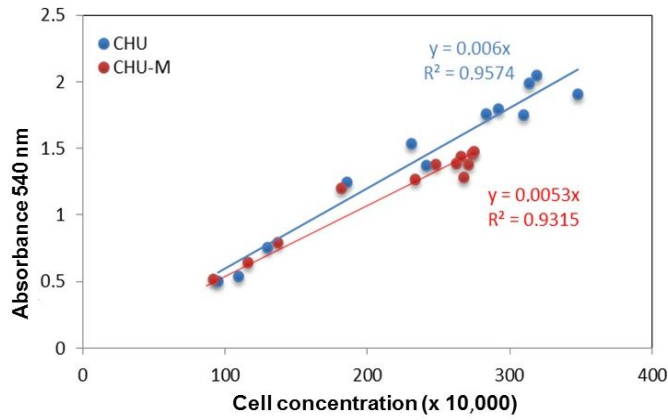

Figure 3. The relationship between the absorbance at a wavelength of $540 \mathrm{~nm}$ and the number of cells in both the culture medium to Chu and modified-Chu.
The biomass produced over time provides information necessary to evaluate the actual productivity of the process. Different microalgae can provide similar results in relation to the number of cells in culture, however, their biomass content can be different. In this work dry biomass was measured every two days to establish the productivity.

Figure 4 shows the results obtained for the dry biomass $\mathrm{gL}^{-1}$. The graph shows the error bars calculated with the same method as in Figure 2. We can observe that, even after the stabilization of the number of cells from the $7^{\text {th }}$ day, dry biomass continues to increase until the 13th day. After 7 days nitrogen levels decrease dramatically (data not shown), and thus the metabolism of amino acids and protein synthesis decreases. All $\mathrm{CO}_{2}$ fixed by microalgae ends being diverted to the synthesis of carbohydrates and lipids resulting in increased cell size.

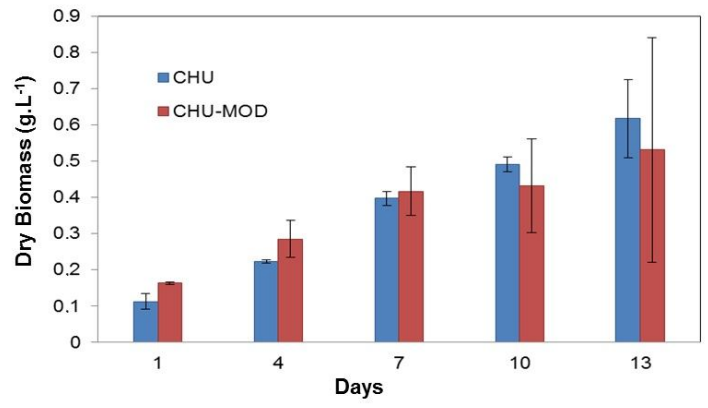

Figure 4. Dry biomass in gram per liter for medium Chu and modified- Chu.

When analyzing the total cost to make $1000 \mathrm{~L}$ of culture medium, with Chu media, it would cost R\$ 4.64 and modified-Chu R\$ 3.74. To determine whether the modified medium is actually more viable than Chu's economic standpoint, an analysis was made of the amount spent per kg biomass, which are shown in Table 2.

Table 2. Production cost to $\mathrm{Chu}$ and modified-Chu medium biomass concentration in gL-1 followed by standard error.

\begin{tabular}{llll}
\hline & $\begin{array}{c}\text { concentration } \\
(\mathbf{g} / \mathbf{L})\end{array}$ & $\begin{array}{c}\text { Price per } \\
\mathbf{1 0 0 0} \mathbf{L} \text { of } \\
\text { medium } \\
(\mathbf{R} \$)\end{array}$ & $\begin{array}{c}\text { Cost of } \\
\text { production } \\
(\mathbf{R} \mathbf{\$} / \mathbf{k g})\end{array}$ \\
\hline Chu & $\begin{array}{l}0.6170 \\
\pm 0.108\end{array}$ & 4.64 & 7.52 \\
& & & \\
Chu & 0.5318 & 3.74 & 7.03 \\
modified & \pm 0.249 & & \\
\hline
\end{tabular}

Table 2 shows that the cost of the modifiedChu medium is approximately $20 \%$ less than the standard Chu. This result is quite advantageous, especially for biomass production on a large scale, 
such as in photobioreactors. However, to know if the modified-Chu medium is really more productive for biodiesel production, we should compare the two media in terms of lipid fraction according to Eq. (2).

Lipid analysis was performed on the last day of culture by the method of Bligh and Dyer, which is based on the use of a monophasic mixture of chloroform, methanol and water (Soares, 2009).

Table 3 shows the results of the amount in percentage of lipids that were found by Equation (2). And the value productivity of lipids found in $1000 \mathrm{~L}$ of medium means Chu and modified-Chu.

Table 3. Amount in\% of Lipid Biomass in the culture with Chu and modified-Chu media.

\begin{tabular}{ccc}
\hline $\begin{array}{c}\text { Means of } \\
\text { Cultivation }\end{array}$ & $\begin{array}{c}\text { Amount of } \\
\text { Lipids } \\
(\%)\end{array}$ & $\begin{array}{c}\text { Lipid } \\
\text { Productivity } \\
\text { (mg/L de means })\end{array}$ \\
\hline Chu & 10.6 & 65.4 \\
$\begin{array}{c}\text { Modified- } \\
\text { Chu }\end{array}$ & 9.3 & 49.4 \\
\hline
\end{tabular}

When we make a relationship with the price of the Chu and Chu - modified media shown in Table 2 , we find the following average values: Chu 71R $\$ / \mathrm{kg}$ of lipids and modified-Chu $7571 \mathrm{R} \$ / \mathrm{kg}$ of lipids.

It is important to point that these values are affected by the variability of biomass productivity illustrated in Figure 4 with a standard deviation, for example in the case of using the largest value of productivity, medium Chu cost $60.4 \mathrm{R} \$ / \mathrm{kg}$ of lipids and modified-Chu $51.5 \mathrm{R} \$ / \mathrm{kg}$ of lipids.

Figure 2 suggest that the growth goes through the well know lag, exponential, and stationary phases. The key idea behind continuous operation mode as opposed to batch is to try to maintain conditions of exponential growth by continuous control of nutrients and harvesting levels. The growth curves in Figure 2 can be used in as an initial step towards the determination of the rates of supply of nutrients/media and harvesting. Since cell levels can vary significantly, rather than specifying a fixed target concentration, it is safer to say that the operation should take place at the concentration levels found in days 6 or 7 in a batch grown in similar conditions.

\section{CONCLUSIONS}

The microalga Scenedesmus sp. was grown for 13 days in two different media: Chu and modifiedChu. This last one was obtained by exchange of the sodium nitrate by urea with $46 \%$ nitrogen content and the sodium phosphate (monobasic and dibasic) by superphosphate. Concentration (via cell count), dry biomass and lipid content were monitored during the experiment.
The cost found to make the modified culture medium is $20 \%$ smaller than the standard culture medium used in our group (NPDEAS). However, due to the large variability observed in lipid productivity, the price of the final product biofuel may vary depending on the range of values covered by the error bars. A future study could be done to reduce variability and optimize growth conditions.

\section{ACKNOWLEDGEMENTS}

$\mathrm{CNPq}$ for financial support and the team NPDEAS whose support was essential to this research.

\section{REFERENCES}

Andrade, M. R., and Costa, J. A., 2008, Cultivo da Microalga Spirulina Platensis em Fontes Alternativas de Nutriente, Ciencia e Agrotecnologia, Vol. 32, No. 5, pp. 1551-1556. (in Portuguese)

Chisti, Y., 2007, Biodisel from Microalgae, Biotechnology Advances, Vol. 25, pp. 294-306.

Chu, S. P., 1942, The Influence of the Mineral Composition of the Medium on the Growth of Planktonic Algae, Journal of Ecology, Vol. 30, pp. 284-325.

Cumming, G., Fidler, F., and Vaux, D. L., 2007, Error Bars in Experimental Biology, The journal of Cell Biology, Vol. 177, No. 1, pp. 7-11.

Le Quéré, C., Andres, R. J., Boden, T., Conway, T., Houghton, R. A., House, J. I., Marland, G., Peters, G. P., van der Werf, G. R., Ahlström, A., Andrew, R. M., Bopp, L., Canadell, J. G., Ciais, P., Doney, S. C., Enright, C., Friedlingstein, P., Huntingford, C., Jain, A. K., Jourdain, C., Kato, E., Keeling, R. F., Klein, G. K., Levis, S., Levy, P., Lomas, M., Poulter, B., Raupach, M. R., Schwinger, J., Sitch, S., Stocker, B. D., Viovy, N., Zaehle, S., and Zeng, N., 2013, The Global Carbon Budget 1959-2011, Earth System Science Data, Vol. 5, pp. 165-185.

Loera-Quezada, and Olguín, E. J., 2010, Las Microalgas Oleaginosas como Fuente de Biodiesel: retos y Oportunidades, Rev. Latinoam Biotecnol Ambiental y Algal, Vol. 1, No. 1, pp. 91-116. (in Spanish)

Mello, T. C., Gnoatto, V. E., Morais, K. C. C., Ribeiro, K., Miyawaki, B., Cardoso, A. T. M., Becker, A., Pulliam, R., Vargas, J. V. C., and Mariano, A. B., 2010, Efeito Econômico da Utilização de Fertilizantes como Substrato no Cultivo de microalgas, in: $5^{\circ}$ Congresso Internacional de Bioenergia., Rio de Janeiro. (in Portuguese)

Morais, K. C. C., 2010, Análise e Desenvolvimento de Aquicultura da Microalga Phaeodactylum Tricomutum em Crescimento Autotrófico e Mixotrófico em Fotobiorreatores Compactos, Master Thesis, Universidade Federal do Paraná, Curitiba. (in Portuguese)

Minowa, T., Yokoyama, S.Y., Kishimoto, M., 
and Okakurat, T., 1995, Oil Production from Algal Cells of Dunaliella Tertiolecta by Direct Thermochemical Liquefaction, Fuel, Vol. 74, pp. 1735-1738.

Oliveira, P. P. A, Trivelin, P. C. O, and Oliveira, W. S., 2003, Eficiência da Fertilização Nitrogenada com Uréia $15 \mathrm{~N}$ em Brachiaria Brizantha cv. Marandu Associada ao Parcelamento de Superfosfato Simples e Cloreto de Potássio, Revista Brasileira do Solo, Vol. 27, No. 4, pp. 613-620. (in Portuguese)

Prabakaran, P., and Ravindran, A. D., 2011, A Comparative Study on Effective Cell Disruption Methods for Lipid Extraction from Microalgae, Letters in Applied Microbiology, Vol. 53, No. 2, pp. 150-154.

Sales, J. C., Sombra, A. S. B., Furtado, A. F. G., and Almeida, J. S., 2006, A Importância do Biodiesel para o Meio Ambiente, in: I Congresso de Pesquisa e Inovação da Rede Norte Nordeste de Educação Tecnológica, Natal-RN. (in Portuguese) 